\title{
Countering Terrorism and Radicalisation, Securitising Social Policy?
}

\begin{abstract}
While social and security policies have always overlapped in complex ways, recent developments in counter-terrorism policy suggest that Western European states, and the United Kingdom more specifically, are accelerating what can be termed the "securitisation of social policy" - namely, the increased submission of social policy actors and their practices to the logics of security and social control. With the Prevent programme remaining highly controversial, what are the effects of these state practices? Has David Cameron's project of "muscular liberalism", aimed at integration and community cohesion, been enforced through counter-radicalisation policies? This themed issue examines preventative counter-terrorism policies in the UK and the politics of religion, ethnicity and race they enact. The relation between social policy and critical security studies is explored by an interdisciplinary group of scholars.
\end{abstract}

Keywords: Multiculturalism, Radicalisation, Suspect Community, Governmentality, Belonging.

\section{Introduction}

The London bombings of July 7 (2005), the murder of Lee Rigby (2013) and the recent departure of hundreds of British citizens for the Syrian conflict are some of the episodes in a long sequence of events that has been labelled "radicalisation" in the United Kingdom (UK) (Githens-Mazer, 2012; Kundnani, 2012). For more than a decade, the UK government has re-oriented counter-terrorism from foreign policy and border control to the domestic realm through policies aimed at tackling "radicalisation". This has resulted in an unprecedented blurring of social and security policies (Abbas, 2005; Klausen, 2009; Spalek and Lambert, 2008; Pickering et al., 2008; Husband and Alam, 2011). Although the logics of security and the logics of welfare have always been intertwined in complex ways, it appears that counterterrorism in Europe, and in particular in the UK with the controversial Prevent programme, has marked an increased foregrounding of security over welfare. How can we disentangle the complex web of relations between these logics and the effects they produce on the populations they target? What are their impacts, not only in terms of civil rights and liberties, but also in terms of identification and sense of belonging? Do the objectives of homogenisation and integration contradict the differentialist policies of targeting "communities"? Can we go beyond the notion of "suspect communities" shared by many of the critics of these policies (Kassimeris and Jackson, 2012; Pantazis and Pemberton, 2009) and analyse the productive effects of the securitisation of social policies? In this themed issue, we propose to examine the policies aimed at the prevention of terrorism based on the politics of religion, ethnicity and race they produce by bringing into dialogue an interdisciplinary group of scholars working at the intersection of social policy and critical security studies.

\section{Counter-terrorism, counter-radicalisation and their effects}




\section{Countering violent extremism in the UK}

While the UK's counter-terrorist policies adopted in the aftermath of attacks in New York and Washington on 11 September 2001 focused on a terrorist threat perceived as coming from abroad - located in Afghanistan, Iraq, or the tribal areas of Pakistan after the Madrid bombings of March 2004 and the London bombings of July 2005, the European Union's (EU's) Muslim populations became the center of attention (Cesari, 2004). The public discourse on terrorism, reframed under the new label of "radicalisation", started to affirm itself in national and European arenas (Bossong, 2007; Coolsaet, 2010).

David Cameron's 2011 speech in Munich crystallised and summarised an emerging discourse, according to which multiculturalism (i.e. diverse ethnic and religious identities are recognised to assure equality for all) was at the root of the problem of domestic terrorism (Cameron, 2011). The speech was in line with a broader trend of repudiating multiculturalism and the development of a new assimilationist discourse (Allen, 2007; Bleich, 2009; Joppke, 2004; McGhee, 2008; see Meer and Modood, 2009, for a critique). The accusation that multiculturalism had led to the development of "parallel lives" - a trope gathered from the Cantle report on the 2001 riots (Great Britain Home Office and Cantle, 2001) - was reinvested by David Cameron's call for "muscular liberalism", which Cameron defined as an "unambiguous and hard-nosed defence of liberty", as well as the defence of "certain values" and their active promotion (Cameron, 2011). The view according to which multiculturalism is in need of replacement is widely shared across Europe (Vertovec and Wessendorf, 2010). Abolishing multiculturalism has been presented as the best way to fight against terrorism; indeed, voices have emerged to support social and cultural policies destined to limit the expression of ethnic, religious and political identities to consensual national identities and "common values". This was then presented as a guarantee of increased security (Veldhuis and Bakker, 2009; Waldmann, 2010).

It is in this context that in 2008-2009, under the informal name of Contest II, the UK government revised the Contest strategy it had established in 2003, with the aim of rationalising the multiple counter-terrorism policies inherited from the previous years. The prevention of radicalisation became one of its most important aspects (House of Commons, 2009). Contest II is structured around four "P"s: Prevent, Pursue, Protect and Prepare. While "Pursue" focuses on detecting, disrupting and prosecuting terrorism plots, "Protect" deals with reinforcing the security of "critical infrastructure", such as the transport system, power plants and public spaces; "Prepare" aims at increasing "resilience" (i.e. the ability of the British population and state agencies to deal with the consequences of an attack), and "Prevent" occupies a place of its own. Prevent has three main objectives: "respond to the ideological challenge of terrorism [...], prevent people from being drawn into terrorism [...] and work with sectors and institutions where there are risks of radicalisation" (HM Government 2011: 7).

In practice, the Prevent programme has gone through two main iterations. Until 2010, under the Labour government, the Home Office emphasised social programmes aimed 
at reinforcing community cohesion and a mentoring scheme, Channel, aimed at rehabilitating individuals considered "at risk" of radicalisation (for more details, see Sabir and Mythen et al. in this issue). In 2007, under the auspices of counterterrorism, local authorities selected on the basis of the proportion of Muslim population were attributed funds to redistribute in community-led projects (Thomas, 2010). The thinking underpinning this policy was that radicalisation is caused in part by social exclusion. In parallel, the Channel programme was built on principles of safeguarding; it established that signs of radicalisation can be detected (see Mythen, Walklate and Peatfield in this issue). In selected local authorities, panels of security and social work professionals were established, with the task of evaluating cases of "radicalisation", entrusting designated cases to mentors for their social rehabilitation or "de-radicalisation".

With the change of majority and the arrival in power of the Conservative-Liberal Democrat Coalition of 2010, the orientation of the Prevent programme shifted away from social programmes and focused on "counter-narratives" and "ideology". Social programmes were discarded as ineffectual and a waste of resources. Instead, the government emphasised countering the ideological dimension of radicalisation by offering counter-narratives to those of Al-Qaeda and the Islamic State. This was developed at the local level, both "offline" at the local level, by empowering initiatives which challenged radicalising discourses, and online, via initiatives targeting internet forums and social media (see more in Sabir in this issue). In 2014, referrals to Channel panels of individuals suspected of radicalisation, while initially expected to occur on a voluntary basis, became a statutory duty for professionals in local government, criminal justice, education and childcare, health and social care and police (Counter-terrorism and Security Act, 2015).

For many activists and political actors, Prevent had been a divisive policy from the start, but its different iterations have broadened the number of critics. In its first iteration, reliance on the "community" as the privileged site of preventing counterterrorism reinforced the idea that terrorism was a problem of the "Muslim community" (Spalek, 2012). As Ratcliffe (2012) and Thomas (2010) have shown, and as Mythen, Walklate and Peatfield. summarise in detail in this themed issue, because of its implementation focused primarily on Muslim populations, the Prevent strategy came under criticism for contradicting the objectives of community cohesion, playing into an islamophobic narrative about the alleged risk posed by the Muslim population as a whole. The enlistment of doctors, nurses, social workers, teachers and other professionals further confirmed the sense that the objective was not rehabilitation of the concerned individuals, but protection of the larger society, at the cost of undermining relations of confidentiality and trust between the professionals and their patients, students (Jarvis and Lister, 2012; Ragazzi, 2016). Finally, the focus on ideology - as exemplified by the controversy over the secret communication activities of the Research, Information and Communications Unit (RICU) in May 2016 reinforced the feeling that Prevent functioned as a covert operation aimed at manipulating public perceptions and ideas (Miller and Sabir, 2013; see also Sabir in this special issue).

Contest, Prevent and the UK's counter-terrorism policy have generated an equal 
amount of criticism in academia, primarily in the fields of criminology and critical security studies. The discourses and practices of exceptionalism that followed September 2001 generated debates around questions of ethics, rights and law. The broad discussion around the "state of exception" spearheaded by Agamben (2005) posed the question of overturning the liberal order and endangering civil liberties in the name of a new raison d'Etat (Aradau and Van Munster, 2009; Bigo, 2007; Huysmans, 2011; Neal, 2012). Work in critical security studies and critical terrorism studies highlighted the constructed and historical contingent definitions of social and political actors as "terrorist threats" (Heath Kelly et. Al. 2014, Jackson 2009). Furthermore, scholars highlighted the effects of the recourse to precaution, preemption and the logics of risk as strategies of anticipation (Amoore and de Goede, 2008; Aradau et al., 2008; Mythen and Walklate, 2008), and in particular Prevent's focus on detecting signs of radicalisation and the constitution of Muslims as sites of intervention, as populations both at risk of becoming radical and potentially risky (Heath Kelly, 2012: 404).

As counter-terrorism became increasingly intertwined with concerns for "community cohesion” (Worley, 2005; Craig, 2013; Thomas and Sanderson, 2013), scholars turned their interest to the impact of these policies on identity and belonging, showing how security policies, and more specifically counter-terrorism policies, have reproduced a racialized and reified conception of Islam (Birt, 2009; Ratcliffe, 2012; Kundnani, 2014; Husband and Alam, 2011; Thomas, 2012). Drawing parallels with the situation in Northern Ireland, and among others on the work of Paddy Hillyard, several authors have shown that Muslims were constituted as the new suspect community in the UK (Bigo and Guittet, 2011; Hickman et al., 2012; Hillyard, 1993; McGovern and Tobin, 2010; Nickels et al., 2012; Pantazis and Pemberton, 2009; Poynting, 2012; Smith, 2012). For many, counter-terrorism policies, including the allegedly "softer" kind aimed at prevention, were therefore working precisely to reinforce the ethno-religious division that was diagnosed as the cause of home-grown terrorism (see Choudhury and Fenwick, 2011; Said, 2004). As others have highlighted, the performativity of counter-terrorism is grounded in the neoliberal principles of active citizenship (Lindekilde, 2012; Mythen and Walklate, 2009; Mythen et al., 2012; Peter, 2008; Thomas, 2012), in which the category of the active, "trusted" Muslim (Ragazzi, 2016) is at least as prominent as that of the Muslim considered to be "risky" or "at risk". Surprisingly, however, despite this growing academic concern, little has been written specifically on the relations among counterterrorism, counter-radicalisation and social policy.

\section{Locating security practices in social policy}

\section{Counter-terrorism, social policy, social control}

To be sure, the questions of security and their constitutive relation to ethnic, racial or religious categorizations have formed a substantial part of the literature in social policy, in particular for those who have approached welfare policy through the problématique of social control (Foucault, 1973, 1977; Garland, 2001; Cohen, 1985; Donzelot, 1979). The policies contained in the Contest strategy and the Prevent programme, and the blurring of social and security policy they entail, can indeed be 
traced back to two key processes that have structured the UK's social policy in past years: the managerial turn of the 1970s and the racialised reframing of social and police work in the 1980s.

The separation of the functions of "care" and "control" is historically contingent. Garland, for one, showed that social policy emerged in the late 19th century from incorporation of the rehabilitative and charitable work carried out by churches and philanthropic societies within the realm of the state along with the retributive functions of punishing crime; he termed this dual function "penal welfarism" (Garland, 2001: 51; Rodger, 2008: 5). The establishment of state-run social services led to the emergence of trained professionals (Perkin, 1989; Polsky, 1991), which in turn conferred on this new class autonomy and discretion in relation to the criminal justice system. A process of "colonisation” (Garland, 2001: 53) of the criminal justice system took place, as psychologists, social workers and youth workers were increasingly consulted and included in the process of sentencing criminals. The underpinning belief was one of "root causes" of crime being found in inequalities and discrimination within society. Professionals in social work developed distinct principles of self-representation similar to those of the philanthropists they replaced, framed as disinterested moral commitments aimed at the rehabilitation of individuals, consistent with the mission that the state had set for itself in the context of penal welfarism (Bisman, 2008: 21; Clark, 2008: 36).

The 1970s, with the experience of two economic shocks, high crime rates and politicisation of immigration, marked a break in the discourse about the welfare mission of the state (Rodger, 2008: 6). While aspects of penal welfarism continued to be applied, their purpose and objectives changed significantly. Managers increasingly replaced welfare professionals (Dahl, 2009; Dominelli and Hoogvelt, 1996; Lund, 1999). Addressing the "root causes" of crime became secondary to "protecting society". The logic of prevention became progressively dominant, as did a new set of principles underpinned by the new penology thinking: risk management, self-reliance and community solutions (O'Malley, 1992; Johnston and Shearing, 2003; Driver and Martell, 1997; Ward and Mullender, 1991; Croft and Beresford, 1989). It is in the turn away from penal welfarism that we find two important transformations in the relation between social work and criminal justice.

The first key effect of the managerial turn is a questioning of the professional distinction made over the years between social work and policing. "Joined-up" teams, multi-agency and community-police partnerships, became the new model of crime prevention grounded in interdisciplinarity and budgetary frugality (Burnett and Appleton, 2004: 35; Pitts, 2003; Kemshall and Wood, 2008: 112). Although some have pointed out the limited implementation of such initiatives (Burnett and Appleton, 2004: 35), we find a core principle of the securitisation of social policy: Narrow, professionalised groups of individuals (police, social workers, youth workers) should not have a monopoly on the maintenance of social order. Instead, the entire spectrum of professions that are in contact with the public should be involved. We find the roots of the current involvement of teachers, university professors, doctors and other professionals in matters of preventive policing and countering extremism (Department of Education, 2015). 
A second key transformation has been the growing importance of race and ethnicity. Authors like Fiona Williams (1989) were among the first to conceptualize the racialized politics of welfare, and its intersection with key categories such as class and gender, and their continuities with the heritage of colonialism. As Gail Lewis showed, while the 1960s were primarily oriented towards the "assimilation of racialised groups of colour in existing social, political and cultural formations", the late 1970s and 1980s saw the emergence of a "cultural pluralist" approach in both policing and social policy (Lewis et al., 2000: 276-277; see also Ratcliffe, 2012). This resulted in strategies aimed at training white social workers to be "ethnically sensitive" and employing "ethnic minority" women as both an equal opportunity policy and recognition of the increasingly multicultural makeup of British society (Lewis, 2000: $4,120)$. While this process can be interpreted as a move towards a more inclusive multicultural society, Lewis showed that it produced a hierarchy of racialised categories of citizens, in particular minority categories perceived to be in need of "particularistic welfare needs", related to essentialised understandings of their gendered, racialised or ethnicised identities (Lewis, 2000: 9). The heteronormative family, in particular, became inscribed in social policy as "the exemplar of responsible parenthood and citizenship" (Lewis, 2005: 545). These trends of dissolving social inequalities into a single notion of social exclusion and re-inscribing the heteronormative family as the core unit of a stable, law-abiding and responsible citizenry, together with the discursive histories of race, coalesced to form the parameters of the government's approach to the question of race in education (Lewis et al., 2000: 278). Therefore, social policy became a key instrument for a particularistic government of difference, where figures like the "black single mother" became specific objectives of intervention, rehabilitation or retribution (Lewis, 2005: 552). This phenomenon was paralleled in the field of policing where specific minorities were targeted as sites for similar forms of interventions (Hall, 1978). We find in Lewis' work several of the processes at play in the subsequent government of the Muslim community through religion (Singh and Cowden, 2011; Modood, 2014a; Singh and Cowden, 2014; Modood, 2014b) in particular in the context of the communitarian turn of New Labour (Lister, 1998; Driver and Martell, 1997; Cain and Yuval-Davis, 1990; Hughes, 1996; Cheong et al., 2007). We also see a focus on young Muslim males as a frequent target of social policy (Mizen, 2003; Alexander, 2004; Muncie, 2006), as well as the problematisation of the Muslim woman (Afshar and Maynard, 1994; Archer, 2001; Dwyer, 1999), with Islam and islamophobia operating as a new layer of othering (Abbas, 2005; Allen and Nielsen, 2002; Poynting and Mason, 2007; Runnymede Trust, 1997).

\section{Conceptualising the securitisation of social policy}

Building on these two processes, we can conceptualise what we term the "securitisation of social policy" ${ }^{1}$ as the product of (1) a future-oriented managerial

\footnotetext{
${ }^{1}$ On the notion of securitisation, see Waever (1991) and c.a.s.e. collective (2006).
} 
conception of policing attached to a (2) racialised conception of the social order. Counter-terrorism and counter-radicalisation policies and objectives can indeed be conceived, first, as particular modes of reasoning premised on the logics of suspicion, anticipation and prediction (Amoore and de Goede, 2008; Aradau and Van Munster, 2009) which belong to specific professionals located within national and transnational social fields (Bigo, 2006; Bonelli and Ragazzi, 2014). In contrast with a growing body of literature in surveillance studies pointing solely towards the role of algorithmic reasoning and "big data", it indeed appears that the rationality of counterradicalisation is to inscribe prediction in the tapping, harnessing and use of social relations as modalities of information gathering, influence and coercion (Ragazzi, 2016). Second, the merging of securitization of social policy operates through a racialised filter: While the majority population is to be policed through a "muscular liberal" conception of community, formed by citizens who entrust the police with a monopoly on the maintenance of social order, counter-radicalisation falls into the logic of the policing of minorities, perceived, through communitarian lenses, as tightly knit face-to-face societies were social control is diffused through multiple "key community figures" such as imams, community leaders and older brothers and sisters, endowed with the responsibility to carry out police and intelligence work ${ }^{2}$. The "securitisation of social policy", in other words, seems to mark a "re-colonisation" of social policy by the security logic, but only for racialised and ethnicised minorities.

\section{Suspicion, Resistance, Trust}

Tackling the question of counter-radicalisation practices through this angle opens at least three lines of research along which the papers of this special issue are organised. First, what are the competing categories of suspicion through which social policy is securitised? This question calls for an analysis of the politics behind the formation of these categories - bureaucratic struggles, forms of symbolic competition, as well as how categories of suspicion, established in official policy documents, become translated, enacted and re-appropriated in local contexts by street-level bureaucrats (Lipsky, 1980). Mythen, Walklate and Peatfield (this issue) show how the concept of radicalisation - which finds its roots in policy and security circles rather than academia - justifies the logic of "indicators" and "signs" as a way to identify processes of political violence. These official categories of suspicion, for failing to rely on a processual, structural and political understanding of political violence, are bound to produce arbitrary categorizations, orienting repressive practices towards racialised categories. Similarly, through analysis of policy documents, parliamentary reports and legislative changes, Choudhury examines how the legal responses to radicalisation are rooted in a colonial history of government of racialised subjects, in which access to citizenship functions as a reward for good behaviour rather than a right. The contemporary injunction for British Muslims, however, is not only to adhere to "moderate" forms of Islam, but to actively embrace vaguely defined

\footnotetext{
${ }^{2}$ I would like to thank François Bonnet for helping me make this distinction clear.
} 
"British values". The threat of the deprivation of citizenship organizes a hierarchy between citizens who are not equals, but divided between "good", "tolerated" and "failed" (on the politics of tolerance, see also Brown, 2006). The importance of categorisation for the logic of counter-terrorism is similarly found by Sabir in his analysis of the influence of military counter-insurgency doctrines in the investment of 'the social' as a specific 'human terrain', constituted as a malleable object of consent. As in military operations, British Muslims become the designated targets of "strategic communication operations" - in other words, propaganda - where the aim is to "win the hearts and minds". As in the article by Choudhury, Sabir shows that these apparently "softer" forms of influence are always embedded in a broader range of practices of power, which include an important degree of coercion.

Second, what are the effects and the forms of resistance produced by these policies? Through which processes do categorised groups accept or subvert "from below" the identities that are attributed to them "from above"? As the contribution of Jarvis and Lister shows most forcefully, the resistance to official policies produces a multiplicity of subject positions grounded in conceptions of family relations, gender and race, which are far more complex than the simple identification to religion. Through the analysis of original focus group data, Jarvis and Lister explore the performativity of counter-terrorism and counter-radicalisation on processes of identification. With the emerging and overlapping categories of "Muslim", "Target”, "Woman" and "Unaffected", the authors show the mutually constitutive dimension of counterterrorism and social identifications. Furthermore, Jarvis and Lister's research on the place of "British values" resonates with Choudhury's legal analysis: in their findings, respondents struggle to "feel British" precisely as a result of their interactions with counter-terrorism and counter-radicalisation policies. Counter-terrorism, they argue, is therefore at odds with the objective of cohesion that lies at the core of "British values" and "muscular liberalism". Through the legal prism, the effects of counterterrorism and counter-radicalisation are drastic: Dual citizenship in particular appears to be a hard-coded category of belonging, underpinned by suspicion through which British Muslims are disciplined. Therefore, counter-terrorism and counterradicalisation not only merge social policy and security concerns, but also create a hierarchy of British citizenship in which access to civil, political and social rights is uncertain and subject to administrative arbitrariness with limited procedural protections. Mythen, Walklate and Peatfield equally conclude their analysis of the "drivers" of radicalisation by acknowledging the importance of state intervention, and in particular the role of state violence, both domestically and abroad, in shaping the "contexts in which commitments to violence become possible"; the ill-defined policies, they argue, end up "potentially criminalizing legitimate political opposition and institutional critique” (Mythen, Walklate, and Peatfield,, this issue). Furthermore, as Sabir shows, through the promotion of acceptable "Muslim representatives" and the imposition of liberal conceptions of 'Islam', the government of terrorism "through the social" curtails political deliberation by reducing issues to questions of management, capacity building or good governance. Thus, as Jarvis and Lister suggest, the practices of "community policing”, while heralded by some as more desirable forms of counter-terrorism, turn segments of the population into both political subjects and subjects of politics. 
Finally, this re-colonisation of social policy by the logics of security poses key normative questions raised by the four papers. The enlistment of the professions into functions of intelligence gathering poses the key question of the place of confidentiality and trust. While not without regular challenges, doctors and psychologists have relied on the Hippocratic oath (Jotterand, 2005; Wynia, 2007), lawyers on the privileged relation with their clients (Hazard, 1978) and priests on the confidentiality of the confessional (Zacharias, 1989), so what are the consequences of asking these professionals to "spot signs of radicalisation" and adopt the role of police(wo)men and intelligence officers? In several instances, policy goals such as public health or prevention of disease have meant that the autonomy of certain professions has prevailed over the logic of surveillance and the repressive hand of the state, as in the case of safe injection rooms and medical assistance to undocumented migrants. However, what is left of this autonomy when it comes to counterradicalisation policies? What are the long-term consequences of subordinating one of the bases of the fabric of democratic societies - relations of trust - to a constant logic of suspicion?

\section{ACKNOWLEDGEMENTS}

Thanks to Didier Bigo, Laurent Bonelli, François Bonnet, Charlotte Heath-Kelly, Paul Thomas and Frank de Zwart who helped me think through many of the issues discussed in this paper.

\section{BIOGRAPHY}

Francesco Ragazzi is lecturer in International Relations at the Institute of Political Science, Leiden University (Netherlands), associate fellow at the Center for International Research (CERI/Sciences Po Paris) and at the Centre d'Etudes sur les Conflits, Liberté et Sécurité (CCLS, France).

\section{REFERENCES}

Abbas T (2005) Muslim Britain: Communities Under Pressure. Zed Books.

Abbas T (2005) Recent Developments to British Multicultural Theory, Policy and Practice: The Case of British Muslims. Citizenship Studies, Routledge, 9(2), 153-166.

Afshar H and Maynard M (1994) The dynamics of ' race’ and gender: Some feminist interventions. Taylor \& Francis.

Agamben G (2005) State of exception. Chicago, University of Chicago Press.

Alexander, C. 2004. "Imagining the Asian Gang: Ethnicity, Masculinity and Youth After 'the Riots'.” Critical Social Policy 24(4): 526-49.

Allen C and Nielsen JS (2002) Summary Report on Islamophobia in the EU after 11 September 2001. EUMC.

Allen, Chris. (2007) “'Down with Multiculturalism, Book-Burning and Fatwas'.” Culture and Religion 8(2): 125-38.

Amoore L and de Goede M (2008) Risk and the War on Terror. Oxon and New York, Routledge.

Aradau C and Van Munster R (2009) Exceptionalism and the 'War on Terror' 
Criminology Meets International Relations. British Journal of Criminology.

Aradau C, Lobo-Guerrero L and Van Munster R (2008) Security, Technologies of Risk, and the Political: Guest Editors' Introduction. Security Dialogue, 39(2-3), 147-154, Available from: http://sdi.sagepub.com/cgi/doi/10.1177/0967010608089159.

Archer L (2001) 'Muslim brothers, black lads, traditional Asians': British Muslim young men's constructions of race, religion and masculinity. Feminism \& Psychology, Sage Publications, 11(1), 79-105.

Bigo D (2007) Detention of foreigners, States of exception, and the social practices of control of the Banopticon. In: Rajaram PK (ed.), Borderscapes, University of Minnesota Press.

Bigo D and Guittet E-P (2011) Northern Ireland as metaphor: Exception, suspicion and radicalization in the 'war on terror'. Security Dialogue 42(6): 483-498.

Bigo, D (2006) Globalized in-Security: the Field of the Professionals of Unease Management and the Ban-Opticon. Traces: a Multilingual Journal of Cultural Theory No. 4/2005: 109-157.

Birt, Y. (2009) 'Promoting virulent envy - reconsidering the UK's terrorist prevention strategy’, Royal United Services Institute (RUSI) Journal, 154:4, 52-58

Bisman C (2008) Personal information and the professional relationship: issues of trust, privacy and welfare. In: [Copy] Private and Confidential?: Handling Personal Information in Social and Health Services: Cynthia Bisman. Bristol: The Policy Press, pp. 17-34.

Bleich, E. (2009) "Muslims and the State in the Post-9/11 West: Introduction." Journal of Ethnic and Migration Studies.

Bolognani, M. (2012) Good culture, bad culture...no culture! The implications of culture in urban regeneration in Bradford, UK. In Critical Social Policy 32 (4), pp. 618-635.

Bonelli, L., and F. Ragazzi (2014) Low-Tech Security: Files, Notes, and Memos as Technologies of Anticipation. Security Dialogue 45, no. 5 (September 29): 476493.

Bossong R (2007) The Action Plan on Combating Terrorism: A Flawed Instrument of EU Security Governance. JCMS: Journal of Common Market Studies, 46(1), 27-48.

Braun, A., Ball, S.J. and Maguire, M. (2011) 'Policy enactments in Schools introduction: towards a toolbox for theory and research', Discourse: Studies in the Cultural Politics of Education, 32:4, 581-583

Brown W (2006) Regulating aversion : tolerance in the age of identity and empire. Princeton, N.J.: Princeton University Press.

Burnett R and Appleton C (2004) Joined-up Services to Tackle Youth Crime. British Journal of Criminology(44): 34-54.

c a s e collective. 2006. Critical Approaches to Security in Europe, a Networked Manifesto. Security Dialogue 37, no. 4: 443-487.

Cain, H.; Yuval-Davis, N. (1990): The 'Equal Opportunities Community' and the anti- 
racist struggle. In Critical Social Policy 10 (29), pp. 5-26.

Cameron D (2011) PM's speech at Munich Security Conference. number10.gov.uk, Available from: http://www.number10.gov.uk/news/speeches-andtranscripts/2011/02/pms-speech-at-munich-security-conference-60293 (accessed 10/02 2011).

Cantle, T. (2001) Community Cohesion - A Report of the Independent Review Team, London: Home Office

Cesari J (2004) When Islam and democracy meet : Muslims in Europe and in the United States. 1st ed. New York, Palgrave Macmillan.

Cheong, P. H.; Edwards, R.; Goulbourne, H.; Solomos, J. (2007): Immigration, social cohesion and social capital: A critical review. In Critical Social Policy 27 (1), pp. 24-49.

Choudhury, Tufyal, and Helen. Fenwick. (2011) The Impact of Counter-Terrorism Measures on Muslim Communities. Manchester: Equality and Human Rights Commission.

Clark C (2008) confidentiality, trust and truthfulness in professional relationships. In: [Copy] Private and Confidential?: Handling Personal Information in Social and Health Services: Cynthia Bisman. Bristol: The Policy Press, pp. 35-48.

Clarke, J. (2005): New Labour's citizens: activated, empowered, responsibilized, abandoned? In Critical Social Policy 25 (4), pp. 447-463.

Cohen S (1985) Visions of Social Control. Cambridge: Polity.

Coolsaet R (2010) EU Counterterrorism strategy: value added or chimera?

Council of the European Union (2005) The European Union Strategy for Combating Radicalisation and Recruitment to Terrorism.

Craig, G. (2013): Invisibilizing 'race' in public policy. In Critical Social Policy 33 (4), pp. 712-720.

Croft, S.; Beresford, P. (1989): User-involvement, citizenship and social policy. In Critical Social Policy 9 (26), pp. 5-18.

Dahl, H. M. (2009): New Public Management, care and struggles about recognition. In Critical Social Policy 29 (4), pp. 634-654.

Department of Education (2015) Protecting children from radicalisation: the prevent duty. Department of Education, Available from: https://www.gov.uk/government/uploads/system/uploads/attachment_data/file/4 39598/prevent-duty-departmental-advice-v6.pdf.

Dominelli, L.; Hoogvelt, A. (1996): Globalization and the technocratization of social work. In Critical Social Policy 16 (47), pp. 45-62.

Donzelot J (1977) La police des familles. Paris: Les Editions de Minuit.

Donzelot J (1979) The policing of families. New York: Pantheon Books.

Driver, S.; Martell, L. (1997): New Labour's communitarianisms. In Critical Social Policy 17 (52), pp. 27-46.

Droit, R.P., and T. Ferenczi (1992) The Left Hand and the Right Hand of the State. Variant no. 32. http://www.variant.org.uk/32texts/bourdieu32.html 
Dwyer C (1999) Veiled Meanings: young British Muslim women and the negotiation of differences [1]. Gender, Place and Culture: A Journal of Feminist Geography, Taylor \& Francis, 6(1), 5-26.

Foucault M (1977) Discipline \& Punish. Random House LLC.

Foucault M (2012) The Birth of the Clinic. Oxon: Routledge.

Garland D (2001) The Culture of Control: Crime and Social Order in Contemporary Society. Oxford: Oxford University Press.

Geddes AFA (1999) The politics of belonging : migrants and minorities in contemporary Europe. Aldershot, England; Brookfield, Vt., Ashgate.

Githens-Mazer J (2012) The rhetoric and reality: Radicalisation and political discourse. International Political Science Review.

Great Britain Home Office and Cantle T (2001) Community cohesion: a report of the independent review team.

Hall S (1978) Policing the crisis: Mugging, the State, and Law and Order / by S. Hall et al. S.l.: Macmillan.

Hazard GC (1978) An Historical Perspective on the Attorney-Client Privilege. California Law Review 66(5): 1061.

Heath-Kelly C (2012) Counter-Terrorism and the Counterfactual: Producing the 'Radicalisation' Discourse and the UK PREVENT Strategy. The British Journal of Politics \& International Relations, 394-415

Heath-Kelly C, Jarvis L and Baker-Beall C (2014) Editors' introduction: critical terrorism studies: practice, limits and experience. Critical Studies on Terrorism, Routledge: $1-10$.

Hickman MJ, Thomas L, Nickels HC, et al. (2012) Social cohesion and the notion of 'suspect communities': a study of the experiences and impacts of being "suspect” for Irish communities and Muslim communities in Britain. Critical Studies on Terrorism 5(1): 89-106.

Hillyard P (1993) Suspect Community: People's Experience of the Prevention of Terrorism Acts in Britain. Pluto Press.

HM Government (2006) Countering international terrorism : the United Kingdom's strategy. Stationery Office. [London], Stationery Office.

HM Government (2011) PREVENT Strategy. London: TSO.

House of Commons (2009) Project CONTEST: The Government's counter terrorism strategy ninth report of session 2008-09 report, together with formal minutes, oral and written evidence. London: Stationery Office.

Hughes, G. (1996): Communitarianism and law and order. In Critical Social Policy 16 (49), pp. 17-41.

Husband C and Alam Y (2011) Social cohesion and counter-terrorism a policy contradiction? Bristol, UK: Policy Press.

Huysmans J (2011) What's in an act? On security speech acts and little security nothings. Security Dialogue, 42(4-5), 371-383.

Jarvis L and Lister M (2012) Disconnected Citizenship? The Impacts of Anti- 
terrorism Policy on Citizenship in the UK. Political Studies, n/a-n/a.

Jackson R, Breen Smith M and Gunning J (2009) Critical terrorism studies: a new research agenda. Routledge. Oxon ; New York: Routledge.

Johnston L and Shearing CD (2003) Governing security: Explorations in policing and justice. London, New York: Routledge.

Joppke, Christian (2004) "The Retreat of Multiculturalism in the Liberal State: Theory and Policy.” The British Journal of Sociology 55(2): 237-57.

Jotterand F (2005) The Hippocratic oath and contemporary medicine: dialectic between past ideals and present reality? The Journal of medicine and philosophy 30(1): 107-128 (accessed 12 May 2016).

Kassimeris G and Jackson L (2012) British Muslims and the discourses of dysfunction: community cohesion and counterterrorism in the West Midlands. Critical Studies on Terrorism, 1-18.

Kemshall H and Wood J (2008) Public protection in practice: Multi-agency Public Protection arrangements (MaPPa). In: Private and Confidential?: Handling Personal Information in Social and Health Services: Cynthia Bisman. Bristol: The Policy Press.

Klausen J (2009) British counter-terrorism after 7/7: Adapting community policing to the fight against domestic terrorism. Journal of Ethnic and Migration Studies, Taylor \& Francis, 35(3), 403-420.

Kundnani A (2012) Radicalisation: the journey of a concept. Race \& Class, 54(2), 325.

Kundnani, A. (2014) The Muslims are Coming: Islamophobia, Extremism and the Domestic War on Terror, London: Verso

Lewis G (2000) 'Race', gender, social welfare: Encounters in a postcolonial society. Cambridge, UK, Malden, MA: Polity Press.

Lewis G (2005) Welcome to the margins: Diversity, tolerance, and policies of exclusion1. Ethnic and Racial Studies 28(3): 536-558.

Lewis G, Gewirtz S and Clarke J (2000) Rethinking Social Policy. London: SAGE Publications.

Lindekilde L (2012) Neo-liberal Governing of 'Radicals': Danish Radicalization Prevention Policies and Potential Iatrogenic Effects. International Journal of Conflict and Violence, 6(1), 109-125.

Lipsky, M. (1980) Street Level Bureaucracy: Dilemmas of the Individual in Public Services, New York: Russell Sage

Lister, R. (1998): From equality to social inclusion: New Labour and the welfare state. In Critical Social Policy 18 (55), pp. 215-225.

Lund (1999) Ask not what your community can do for you' obligations New Labour and welfare reform, Critical Social Policy, 19(4), pp.

McGhee, D. (2006) 'The new Commission for Equality and Human Rights: Building Community Cohesion and revitalising citizenship in contemporary Britain', Ethnopolitics, 5:2, 145-166 
McGhee, Derek. (2008) The End of Multiculturalism? : Terrorism, Integration and Human Rights. Maidenhead: Open University Press.

McGovern M and Tobin A (2010) Countering Terror or Counter-Productive: Comparing Irish and British Muslim Experiences of Counter-insurgency Law and Policy. Edge Hill University. Ormskirk: Edge Hill University.

Meer, Nasar, and Tariq Modood. (2009) "The Multicultural State We're in: Muslims, 'Multiculture' and the 'Civic Re-Balancing' of British Multiculturalism.” Political Studies 57(3): 473-97.

Miller D and Sabir R (2013) Counter-terrorism as counterinsurgency in the UK 'war on terror'. In: Poynting S and Whyte D (eds) Counter-Terrorism and State Political Violence: The 'War on Terror' as Terror Counter-Terrorism and State Political Violence: The 'War on Terror' as Terror. London: Routledge, pp. 1232.

Mizen, P. 2003. "The Best Days of Your Life? Youth, Policy and Blair's New Labour.” Critical Social Policy 23(4): 453-76.

Modood, T. (2014a): Part one Accommodating religions: Multiculturalism's new fault line. In Critical Social Policy 34 (1), pp. 121-127.

Modood, T. (2014b): Part three The fault lines of multiculturalism: A rejoinder. In Critical Social Policy 34 (1), pp. 135-139.

Muncie, J. 2006. "Governing Young People: Coherence and Contradiction in Contemporary Youth Justice.” Critical Social Policy 26(4): 770-93.

Mythen G and Walklate S (2008) Terrorism, Risk and International Security: The Perils of Asking 'What If?'. Security Dialogue, 39(2-3), 221-242.

Mythen G and Walklate S (2009) 'I'm a Muslim, but I'm not a Terrorist':

Victimization, Risky Identities and the Performance of Safety. British Journal of Criminology.

Mythen G, Walklate S and Khan F (2012) 'Why Should We Have to Prove We're Alright?” : Counter-terrorism, Risk and Partial Securities. Sociology.

Nickels HC, Thomas L, Hickman MJ, et al. (2012) Constructing 'suspect' communities and Britishness: Mapping British press coverage of Irish and Muslim communities, 1974-2007. European Journal of Communication 27(2): 135-151.

Noiriel, G (1996) The French Melting Pot : Immigration, Citizenship, and National Identity. Minneapolis London: University of Minnesota Press.

O'Malley P (1992) Risk, power and crime prevention. Economy and Society 21(3): 252-275 (accessed 6 May 2016).

Osler, Audrey (2012) ‘Citizenship Education and Diversity’, in: J.A. Banks (Ed.) Encyclopaedia of Diversity in Education. Vol. 1. Sage: London and Los Angeles, CA, pp. 353-361.

Pantazis C and Pemberton S (2009) From the 'Old' to the 'New' Suspect Community: Examining the Impacts of Recent UK Counter-Terrorist Legislation. British Journal of Criminology, 49(5), 646-666.

Pantazis C and Pemberton S (2009) From the 'Old' to the 'New' Suspect Community: 
Examining the Impacts of Recent UK Counter-Terrorist Legislation. British Journal of Criminology, Oxford University Press 49(5): 646-666.

Perkin HJ (1989) The rise of professional society: England since 1880. London, New York: Routledge.

Peter F (2008) Political Rationalities, Counter-terrorism and Policies on Islam in the United Kingdom and France. In: Eckert J (ed.), The Social Life of AntiTerrorism Laws, Transcript Verlag, pp. 79-108.

Phillips D (2006) Parallel lives? Challenging discourses of British Muslim selfsegregation. Environment and Planning D, PION LTD, 24(1), 25.

Pickering S, McCulloch J and Wright-Neville D (2008) Counter-terrorism policing: towards social cohesion. Crime, Law \& Social Change 50(1-2): 91-109.

Pitts J (2003) The New Politics of Youth Crime: Russell House Pub Limited.

Polsky AJ (1991) The rise of the therapeutic state. Princeton, N.J.: Princeton University Press.

Poynting S (2012) Counter-Terrorism and State Political Violence. Routledge.

Poynting S and Mason V (2007) The resistible rise of Islamophobia Anti-Muslim racism in the UK and Australia before 11 September 2001. Journal of Sociology, Sage Publications, 43(1), 61-86.

Ratcliffe P (1998) 'Race', Housing and Social Exclusion. Housing Studies, Taylor \& Francis, 13(6), 807-818.

Ratcliffe, P. (2012): 'Community cohesion': Reflections on a flawed paradigm. In Critical Social Policy 32 (2), pp. 262-281.

Rodger J (2008) Criminalising Social Policy. Portland, Oregon: Willan Publishing.

Runnymede Trust LUK (1997) Islamophobia A challenge for us all.

Shain, Farzana. 2011. The New Folk Devils: Muslim Boys and Education in England. Stoke-On-Trent: Trentham Books Ltd.

Singh, G.; Cowden, S. (2011): Multiculturalism's new fault lines: Religious fundamentalisms and public policy. In Critical Social Policy 31 (3), pp. 343364.

Singh, G.; Cowden, S. (2014): Part two Response to Tariq Modood - Accommodating religions: Who's accommodating whom? In Critical Social Policy 34 (1), pp. 128-134.

Smith WB (2012) State violence, collusion and the troubles - counterinsurgency, government deviance and Northern Ireland, by Maurice Punch. Critical Studies on Terrorism 5(3): 515-518.

Spalek B (2012) Counter-Terrorism. Community-Based Approaches to Preventing Terror Crime. Basingstoke : Palgrave Macmillan.

Spalek B and Lambert R (2008) Muslim communities, counter-terrorism and counterradicalisation: A critically reflective approach to engagement. International Journal of Law, Crime and Justice, 36(4), 257-270.

Thomas P (2012) Responding to the Threat of Violent Extremism. Bloomsbury Academic. 
Thomas, P. (2011) Youth, Multiculturalism and Community Cohesion, Basingstoke: Palgrave Macmillan

Thomas, P.; Sanderson, P. (2013): Crossing the line? White young people and community cohesion. In Critical Social Policy 33 (1), pp. 160-180.

Thomas, Paul. 2010. "Failed and Friendless: The UK's 'Preventing Violent Extremism' Programme.” The British Journal of Politics \& International Relations 12 (3): 442-58. doi:10.1111/j.1467-856X.2010.00422.x.

Veldhuis T and Bakker E (2009) Muslims in the Netherlands : Tensions and Violent Conflict. Social Science, (May).

Vermeulen F and Bovenkerk F (2012) Engaging with Violent Islamic Extremism. The Hague, Eleven International Publishing.

Vertovec, Steven, and Susanne Wessendorf. 2010. The Multiculturalism Backlash. Taylor \& Francis. Oxon and New York: Taylor \& Francis.

Waldmann PK (2010) Radicalisation in the Diaspora : Why Muslims in the West Attack Their Host Countries (WP).

Ward, D.; Mullender, A. (1991): Empowerment and oppression: An indissoluble pairing for contemporary social work. In Critical Social Policy 11 (32), pp. 2130.

Williams F (1989) Social policy : a critical introduction : issues of race, gender, and class. Cambridge, UK; Oxford, Uk; New York, NY, USA: Polity Press ; Blackwell.

Worley, C. (2005): 'It's not about race. It's about the community': New Labour and 'community cohesion'. In Critical Social Policy 25 (4), pp. 483-496.

Wynia MK (2007) Breaching confidentiality to protect the public: evolving standards of medical confidentiality for military detainees. The American journal of bioethics AJOB 7(8): 1-5 (accessed 12 May 2016).

Zacharias F (1989) Rethinking Confidentiality. Iowa Law Review(2): 351-412. 